\title{
Assessing the spatial distribution of urban soil lead contamination in Yogyakarta City, Indonesia
}

\author{
Andria Tri Sekarningsih ${ }^{1}$, Wawan Budianta ${ }^{1, *}$ I Wayan Warmada ${ }^{1}$, Hirofumi Hinode ${ }^{2}$ \\ ${ }^{1}$ Department of Geological Engineering, Universitas Gadjah Mada, Yogyakarta, Indonesia \\ ${ }^{2}$ Tokyo Institute of Technology, Japan
}

\begin{abstract}
Yogyakarta is currently a developing city in Indonesia, and urbanization is a very relevant issue. One of the impact of urbanization was soil pollution which becomes an important and interesting environmental concern. This research aimed investigate lead $(\mathrm{Pb})$ pollution level distribution using spatial analysis on lead $(\mathrm{Pb})$ distribution in the soil at Yogyakarta city and its surroundings. The determination of the soil sampling location point was carried out using the gridding method, and the soil sampling was obtained at a depth of $10 \mathrm{~cm}$. The concentration of lead $(\mathrm{Pb})$ in the soil samples was measured using ICP-AES. The spatial analysis was carried out by making a level of distribution map of the lead $(\mathrm{Pb})$ and then overlaying it with the data of residential, traffic, and industrial densities. These research results indicated that anthropogenic factors influenced the lead $(\mathrm{Pb})$ concentration in the soil's soil more than natural factors. The anthropogenic factors of settlement and traffic densities were thought to contribute most to the lead concentration in the soil at the research site. The industrial presence factor was less likely to contribute to the high $\mathrm{Pb}$ concentration in the soil at the study area.
\end{abstract}

\section{Introduction}

Heavy metals in soil, especially lead $(\mathrm{Pb})$, can potentially have severe impacts on the environment and human health $[1,2]$. Until today, $\mathrm{Pb}$ has still been considered a pollutant that can cause soil and environmental pollution [3]. Yogyakarta is one of the currently developing cities because it is one of the world's tourist destinations; thus, urbanization is a very relevant issue [4]. An implication of urbanization in Yogyakarta is air pollution by lead $(\mathrm{Pb})$, which is $0.3656-75.7 \mathrm{mg} / \mathrm{m}^{3}$, which has passed the allowable threshold of $2 \mathrm{mg} / \mathrm{m}^{3}$ [5]. Another more important thing is the decreasing in the surface soil quality in Yogyakarta City and its surroundings. Research conducted by Budianta (2012) [6] showed that the Pb content on the soil surface in urban and suburban sites of Yogyakarta varied from 25 to $95.50 \mathrm{mg} / \mathrm{kg}$, with an average value of $64 \mathrm{mg} / \mathrm{kg}$. The $\mathrm{Pb}$ concentration in the city center has about $62 \mathrm{mg} / \mathrm{kg}$, five times that in the suburbs $(14 \mathrm{mg} / \mathrm{kg})$. Based on this description, research studying the surface soil contaminated by lead $(\mathrm{Pb})$ in Yogyakarta City for 2021 was then required, as well as to determine the contamination level development by conducting a more comprehensive spatial analysis of the lead $(\mathrm{Pb})$ distribution in the soil at the research site. The study area was located in Yogyakarta city, Indonesia and its surroundings area as shown in Figure 1.
The soil sampling location was determined using the gridding method, where the research site was on a grid with each outer grid of $1.5 \mathrm{~km} \mathrm{x} 1.5 \mathrm{~km}$ (Figure 2). The sampling point was attempted to be in the middle of the grid, representing each grid site. The soil sampling was carried out by hand drill at a depth of $10 \mathrm{~cm}$, assuming that it meant the topsoil layer. The determination of the sampling location point was done using GPS. Also, the soil sampling was carried out by considering avoiding locations close to pollutant sources, such as trash bins or incineration sites, to prevent anomalies in the lead $(\mathrm{Pb})$ content that was too high; therefore, a more general overview of lead $(\mathrm{Pb})$ content in the site was obtained. For the lead $(\mathrm{Pb})$ analysis, the soil sample taken in the field was put into a sample plastic and was prepared for laboratory analysis. All soil samples were then dried at room temperature for approximately one week. Then they were smoothed or homogenized using an agate mortar and pestle to obtain a fine sample $(<2 \mathrm{~mm})$ referring to Argyraki and Kelepertzis (2014) [1]. The lead (Pb) analysis in the soil sample was carried out using ICP-AES (Inductively Coupled Plasma - Atomic Emission Spectrometry) at the Tokyo Institute of Technology, Japan.

\section{Materials and methods}

\footnotetext{
* Corresponding author: wbudianta@ugm.ac.id
} 


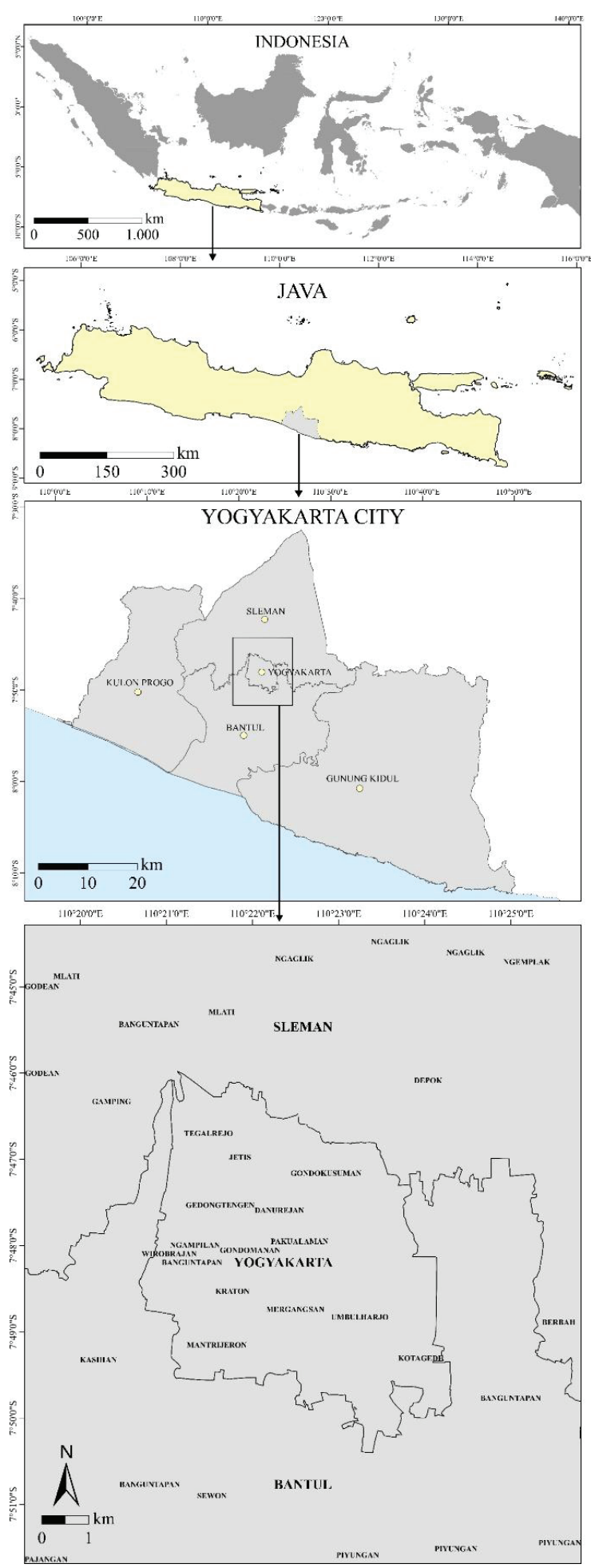

Fig. 1. The study area

The lead $(\mathrm{Pb})$ concentration was measured after the soil sample was dissolved in strong acid ( $\mathrm{HF}-\mathrm{HCl}$ and $\mathrm{HNO}_{3}$ ), followed by the dissolution using microwave as descibed by Bettinelli et al, 2000 [7]. The $\mathrm{Pb}$ distribution analysis in the soil sample was carried out spatially. The lateral distribution was carried out based on the lead $(\mathrm{Pb})$ content in the sample from all sampling points by making a level of distribution map of the lead $(\mathrm{Pb})$. The results of the lateral distribution analysis associated with several parameters -mainly anthropogenic factors such as settlement, traffic, and industry densities - were expected to provide information about the factors that affected the lead $(\mathrm{Pb})$ distribution in the soil at the research site.

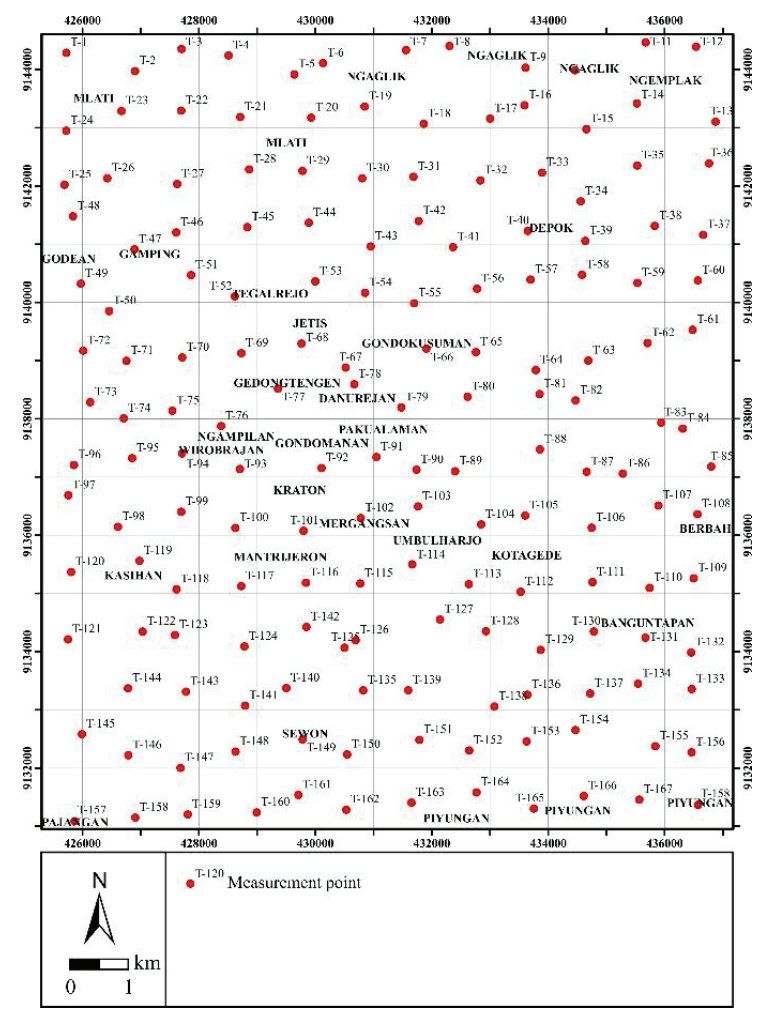

Fig. 2. The sampling point location

\section{Result and Discussion}

The geological conditions of the Yogyakarta urban area are mostly composed of volcanic materials from young Merapi volcano [8]. These materials were from the sedimentation of the lava flow, pyroclastic flow, and clastic volcanic sedimentation during the Quaternary (Pleistocene-Holocene) period [8]. Physically, the volcanic material that covers the urban area of Yogyakarta (Yogyakarta City and parts of Sleman and Bantul regencies) has not been consolidated and is loose [9]. The lithology of this young Merapi volcanic deposit is composed of fine-medium and gravel sand, where the fine-medium sand is composed of alternating fine and medium sand, and there are some insertions of silt and clay [9]. The outcrop of volcanic material can be well seen on the river slopes that pass through Yogyakarta. The rock-forming materials in Yogyakarta City are derived from volcanic material from Merapi volcano, which is limestone-alkaline, basaltic, andesite with high $\mathrm{K}$-content with a $\mathrm{SiO}_{2}$ composition ranging from $52-57 \%$. The mineralogy of the Merapi volcano eruption material is plagioclase, clinopyroxene (augite-salite), brown hornblende, olivine, and hypersthenes [10]. In addition to these volcanic materials, volcanic ash also plays a role in 
forming soil and rock constituent materials at the research site, containing silica minerals. The most common elements are sulfate, chloride, sodium, calcium, and magnesium fluoride [10]. Most of the volcanic material has undergone weathering, so that several places in the urban area of Yogyakarta have formed quite thick soil above the urban periphery of Yogyakarta. Spatially, the distribution pattern of lead $(\mathrm{Pb})$ in the surface soil at the study area can be seen in Figure 3.

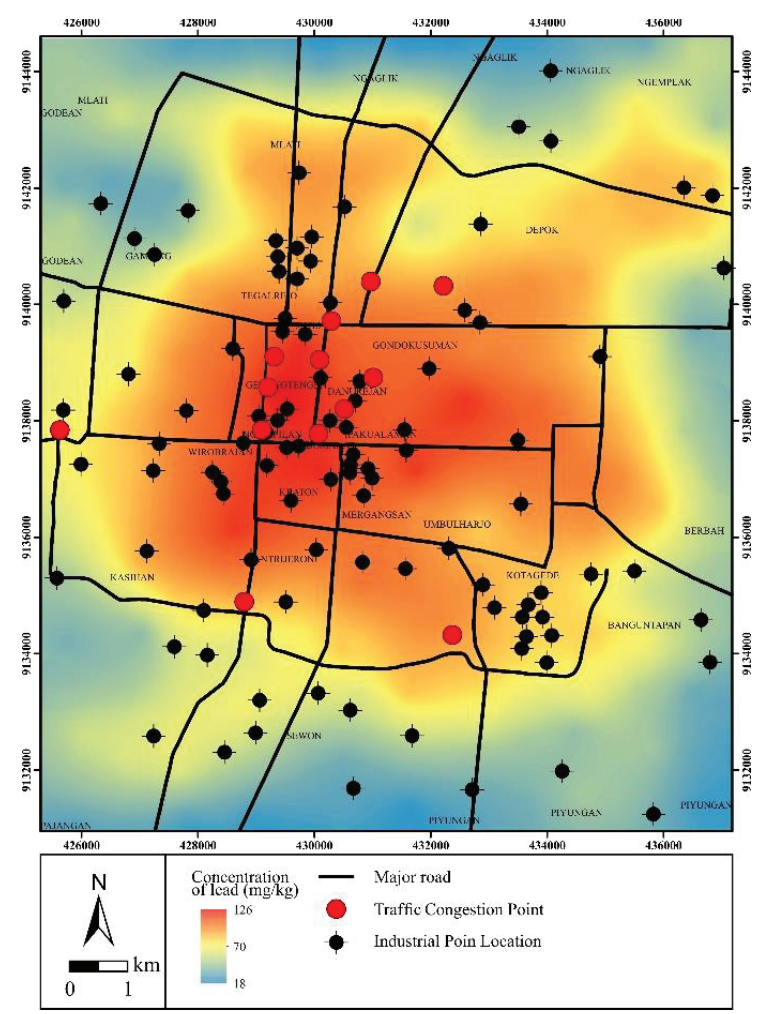

Fig. 3. Spatial distribution of lead $(\mathrm{Pb})$

The $\mathrm{Pb}$ concentration at the center of the research site, the city center, commonly had a higher $\mathrm{Pb}$ concentration than the surrounding area. Figure 3 is an overlay map of the distribution of lead $(\mathrm{Pb})$ concentration in the soil at the research site and the map of roads, residential densities, and industrial locations. The spatial analysis was carried out by observing the lead $(\mathrm{Pb})$ distribution pattern and then associated with several factors considered influential, both natural and anthropogenic. In detail, it will be discussed one by one in the following description. Natural or geogenic factors in the presence of lead $(\mathrm{Pb})$ in the soil can occur due to the enrichment process of the original rock that has undergone weathering at the research site. As explained in the previous description, most of the study area consist of volcanic material from Merapi volcano, which was not consolidated and a loose material. The rock constituent materials in Yogyakarta City come from volcanic materials of Merapi volcano, which are limestone-alkaline, basaltic, and andesite with high K-content. Elements in volcanic soils generally are $1.8-5.9 \% \mathrm{Al}, 1-2.4 \% \mathrm{Mg}, 2.6-2.8 \% \mathrm{Si}$, and $1.4-9.3 \% \mathrm{Fe}$ [11]. From this description, it can be interpreted that the lead $(\mathrm{Pb})$ content in volcanic rocks naturally has a low value [12]. Generally, the increase in the lead $(\mathrm{Pb})$ concentration in the soil at the study area can be concluded to be influenced by human activities. The second factor influencing the distribution and increase of lead $(\mathrm{Pb})$ concentration in the soil at the study area was the residential and population factors. One of the materials that humans often use as a source of the lead $(\mathrm{Pb})$ is the use of paint. Things that need to be considered for residential factors are house paint, the pattern of settlement density distribution, age of settlement, condition, type of the house, and housing distance to traffic density. The population density of the study area revealed that the settlement density was generally concentrated in the center of the map, or the center of Yogyakarta City, which generally had an older age of settlement compared to their surroundings. The next factor was vehicle emissions that might increase the lead $(\mathrm{Pb})$ concentration in the soil at the study area. Figure 3 shows that the main roads and congestion traffic points were more dominant in the city center, where vehicle emission was more prevalent in this area. This vehicle emission was interpreted to have contributed significantly to the high concentration of lead $(\mathrm{Pb})$ at this area. The distance from the main road, which was the source of vehicle emissions, and the high level of settlement in this area made two factors that simultaneously contributed significantly to the high concentration of $\mathrm{Pb}$ in the soil at study area. Several study shows that the vehicle emission has significant contribution on the lead $(\mathrm{Pb})$ contaminated soil in urban area $[13,14]$. Another factor that was interpreted to be contributing was other human activities, such as industry and waste disposal. The map of Figure 3 shows that the city center dominated the presence of the industry at the study area despite there were some industrial locations outside the city at the study area. However, Figure 3 also shows several points of the industrial presence outside the city that less contributed to the high concentration of $\mathrm{Pb}$ in the soil at that location.

\section{Conclusion}

The spatial analysis results of overlaying several maps can be concluded that the anthropogenic factors influenced the lead $(\mathrm{Pb})$ concentration in the soil at the study area more than the natural factors. The geological and soil conditions at the study area, which were composed of young volcanic material, would contribute to low concentrations of lead $(\mathrm{Pb})$ in the soil due to the low lead $(\mathrm{Pb})$ content in host rocks at the study area. The anthropogenic factors such as settlement and traffic densities were interpreted to contribute most to the lead $(\mathrm{Pb})$ concentration in the soil at the study area. The presence of the industrial factor did not seems have contribution to the high concentration of lead $(\mathrm{Pb})$ in the soil at the study area.

Authors thank to Universitas Gadjah Mada for the supporting research funding. 


\section{References}

1. A. Argyraki and E. Kelepertzis, Sci. Total. Environ. 482 (2014)

2. M. Gaberšek and M. Gosar, J. Geochem. Explor. 187 (2018)

3. M. Andersson, R.T. Ottesen and M. Langedal, Geoderma 156, 3-4 (2010)

4. W. Pradoto, Intern. J. Arts. Sci. 4, 27 (2011)

5. Z. Abidin and S. Sunardi, Indones. J. Chem 9, 3 (2010)

6. W. Budianta, J. South East Asia Appl. Geology. 4, 2 (2012)

7. M. Bettinelli, G.M. Beone, S. Spezia and C. Baffi, Anal. Chim. Acta. 424, 2 (2020).

8. W. Rahardjo, H.M.D Rosidi and Sukandarrumidi (1995)

9. S.M MacDonald, Greater Yogyakarta Groundwater Resources Study (1984)

10. G. Camus, A. Gourgaud, P.C. Mossand-Berthommier and P.M. Vincent, J. Volcanol. Geotherm. Res. 100 (2000)

11. Sudaryo and Sucipto, Identifikasi dan penentuan logam pada tanah vulkanik di daerah Cangkringan Kabupaten Sleman dengan metode analisis aktivasi neutron cepat, in Prosiding Seminar Nasional V SDM Teknologi Nuklir, 5 November (2009)

12. H. Meuser, Contaminated urban soils (Springer, London, 2010)

13. I.D. Yesilonis, R.V. Pouyat, and N.K. Neerchal, Environ. Pollution, 156, 3 (2008)

14. D.S. Manta, M. Angelone, A. Bellanca, R. Neri, and M. Sprovieri, Sci.Total. Environ. 300, 1-3 (2002) 